\title{
REGENERATION OF ATHROTAXIS SELAGINOIDES AND OTHER RAINFOREST TREE SPECIES ON LANIDSLIDE FACES IN TASMANIA
}

\author{
by Phil Cullen
}

(with four tables and two text-figures)

\begin{abstract}
Seedling surveys indicated that landslide faces provide opportunities for Athrotaxis selaginoides and Nothofagus cunninghamii to regenerate in thamnic and high altitude callidendrous rainforest. The spatial distribution of mature $A$. selaginoides stems at some sites suggests that they have originated on past landslides. Leptospermum scoparium and Eucalyptus vernicos seedlings were also present at some of the sites investigated. Therefore, landslides may provide regeneration opportunities for these species in rainforest communities in the absence of fire.

The physical attributes of $A$. selaginoides suggest that the species would be advantaged by canopy disturbance of the scale caused by landslides as opposed to smaller treefall gaps. The cooler climate, higher levels of slope instability, avalanches and snowstorms during the last glacial would have been well suited to this species.
\end{abstract}

Key Words: Athrotaxis selaginoides, rainforest, regeneration, Tasmania.

In BANKS, M.R. et al. (Eds), 1991 (31:iii): ASPECTS OF TASMANIAN BOTANY - A TRIBUTE TO WINIFRED CURTIS. Roy. Soc. Tasm. Hobart: 191-200. https://doi.org/10.26749/rstpp.124.2.191

\section{INTRODUCTION}

Recent research has demonstrated that Athrotaxis selaginoides (nomenclature follows Buchanan et al. 1989) is reliant upon canopy disturbance, resulting from reefalls or natural catastrophes, for regeneration opportunities in evergreen rainforests (Cullen 1987a, Read \& Hill 1988a). Infrequent catastrophic disturbances in one form or another are now seen as integral components of many forest ecosystems (e.g. White 1979). In southem South America and New Zealand, events such as landslides and rockfalls (often caused by seismic activity), avalanches, burial by volcanic debris, fires, windstorms, and floods are common and can cause widespread disturbances in cool temperate rainforests in montane and subalpine areas. Many conifer and Nothofagus species rely upon catastrophic disturbances to maintain their positions of dominance in these forests from one generation to the next (Hutchinson 1932, McKelvey 1953, Lloyd 1960, Cameron 1960, Beveridge 1973, Wardle 1970, 1974, Burke 1974, Clayton-Green 1977, Veblen \& Ashton 1978, Veblen 1982, Veblen \& Stewart 1982, Norton 1983, Veblen et al. 1983, Veblen \& Lorenz 1987). However, Tasmania has no volcanoes, seismic activity is much less intense and the mountains here do not receive large snowfalls or support glaciers. As a consequence, catastrophic disturbances caused by these agents do not achieve the same prominence in the landscape as they do in either southern South America or New Zealand.
At present, fire is the major form of catastrophic disturbance in $A$. selaginoides dominated forests. However, fire is more likely to destroy the species than promote its regeneration. The fire regime since the arrival of Europeans in Tasmania has resulted in the loss of large areas of rainforest and alpine vegetation within the range of the species (Kirkpatrick \& Dickinson 1984a, b). Brown (1988) estimates that about $30 \%$ of standing $A$. selaginoides stems have been killed by fire.

In Tasmania, plant ecologists have paid much attention to the effects of fire (for example Jackson 1968, Mount 1979, Kirkpatrick \& Dickinson 1984a). With the exception of Hughes (1987), who studied the effects of floods on riparian and aquatic plant communities, there have been no ecological studies dealing with other forms of catastrophic disturbance.

The present frequency of catastrophic disturbances, other than fire, in forests containing $A$. selaginoides is not known. However, landslides and rockfalls are common on steep slopes in the high rainfall, mountainous, western and southern regions of Tasmania. They occur on a variety of rock types, often in areas supporting thamnic or high altitude callidendrous rainforest dominated by $A$. selaginoides and Nothofagus cunninghamii (see Jarman et al. 1984 for definitions of rainforest terminology). It seems probable that landslides could create conditions suitable for A. selaginoides regeneration (Cullen 1987a). Linear stands of $A$. selaginoides, perpendicular to the contours, on steep mountain slopes, have been sighted from the air in the south of the state. These stands may have established on past landslides, thus accounting for their orientation. 
This study was conducted to assess the suitability of landslides as sites for regeneration of $A$. selaginoides and other tree species in thamnic and high altitude callidendrous rainforests.

\section{METHODS}

Landslides and rockfalls were investigated at Frenchmans Cap (quartzite), Mt Victoria Cross (sandstone), and at Dunning Rivulet on the Great Westem Tiers (dolerite) (fig. 1). In all, six study sites were selected at these three localities (table 1), located on areas disturbed by landslide or rockfall and adjacent to mature rainforest containing A. selaginoides trees. At each site, forest composition was investigated using $5 \mathrm{~m}$ wide transects of varying lengths. The transects were orientated parallel to the contours and located so as to cross the centres of the areas disturbed by landslide and to extend into undisturbed forest.

Along each transect the height of seedlings of all species capable of growing to be trees and the diameter of all tree species greater than $10 \mathrm{~mm}$ d.b.h. were recorded. Recording was terminated when approximately 200 individuals were measured. The projected cover of all species was estimated, using Braun-Blanquet cover classes.

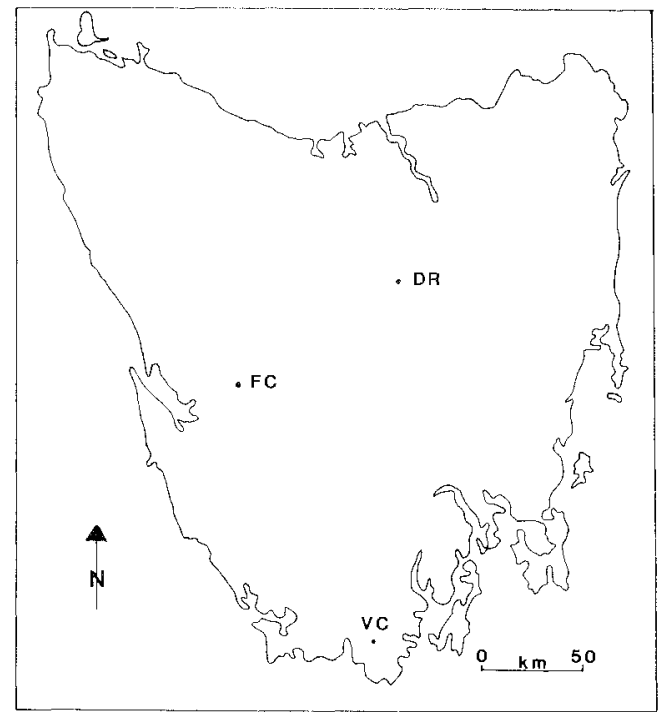

FIG. 1 - Location of the three areas of study for landslides and rockfalls. $D R=$ Dunning Rivulet, $F C=$ Frenchmans Cap, VC $=$ Mt Victoria Cross.

TABLE 1

Stand Designation, Locality and Characteristics of Study Sites

\begin{tabular}{|c|c|c|c|c|c|c|}
\hline Stand/designation & $\begin{array}{c}\text { Grid } \\
\text { reference }\end{array}$ & $\begin{array}{c}\text { Altitude } \\
\text { (m) }\end{array}$ & Aspect & $\begin{array}{c}\text { Slope } \\
\left({ }^{\circ}\right)\end{array}$ & Parent material & $\begin{array}{c}\text { Soil pH } \\
\text { (top } \\
100 \mathrm{~mm} \text { ) }\end{array}$ \\
\hline \multicolumn{7}{|l|}{ Frenchmans Cap } \\
\hline $\mathrm{FCl}$ & 043193 & 900 & SW & $30-35$ & Quartzite & 4.5 \\
\hline $\mathrm{FC} 2$ & 059912 & 820 & SE & $25-30$ & Quartzite & 4.5 \\
\hline \multicolumn{7}{|l|}{ Mt Victoria Cross } \\
\hline $\mathrm{VC} 1$ & 721876 & 920 & WNW & $20-25$ & Sandstone/dolerite talus & 4.5 \\
\hline $\mathrm{VC} 2$ & 722878 & 920 & WNW & $20-25$ & Sandstone/dolerite talus & 4.5 \\
\hline VC3 & 723881 & 920 & WNW & $20-25$ & Sandstone/dolerite talus & 4.5 \\
\hline \multicolumn{7}{|l|}{ Dunning Rivulet } \\
\hline DR2 & 683775 & 980 & WNW & 17.5 & Dolerite & 5 \\
\hline
\end{tabular}


Seedling densities for disturbed and undisturbed forests were calculated. Percentage frequencies for seedlings and adults of all tree species in $100 \mathrm{~mm}$ size classes were determined for each stand, the size classes used being $1=<10 \mathrm{~mm}$ d.b.h. (seedlings), $2=10$ $95 \mathrm{~mm}, 3=100-195 \mathrm{~mm}$ and ensuing $100 \mathrm{~mm}$ size classes. A positive relationship between size and diameter was assumed for $A$. selaginoides (Ogden 1978 and Cullen 1987a). Read \& Hill (1988a) found a positive relationship between age and diameter for $N$. cunninghamil, Atherosperma moschatum, Eucryphia lucida, Phyllocladus aspleniifolius and Athrotaxis selaginoides at a number of sites. Therefore, trunk diameter can be used as a crude estimate of stem age for these species. Increment cores were taken from mature A. selaginoides stems at stands $\mathrm{DR} 2, \mathrm{FC} 1, \mathrm{VC} 2$ and VC3 to obtain estimates of minimum age since disturbance and the period for which the site was open to $A$. selaginoides recruitment.

The cover class information for the species recorded at each site was tabulated and sorted with the assistance of the ecological data base system ECOPAK (Minchin 1986).

The mature forests at the study sites were classified subjectively according to the rainforest classification of Jarman et al. (1984) and by comparison to the forests described by Cullen (1987b).

Aerial photographs at a scale of 1:20 000 were used to assess the incidence of landslides in the Mt Victoria Cross region. Unfortunately aerial photographs of a suitable scale were not available for the other regions investigated.

\section{RESULTS AND DISCUSSION}

The sites investigated support either thamnic or high altitude callidendrous rainforest. Although floristic composition and canopy height of the forests varies from site to site, in all cases the main canopy is formed by an unbroken stratum dominated by Nothofagus cunninghamii with emergent Athrotaxis selaginoides and scattered individuals of Atherosperma moschatum, Eucryphia lucida or E. milliganii, and Phyllocladus asplenilfolius. Beneath the main canopy a layer of broad leaf shrubs, the palm-like Richea pandanifolia, and, at the Mt Victoria Cross sites, $R$. scoparia form a discontinuous second stratum. The ground layer at all the sites is composed of scattered shrubs, mosses, fems, and herbs, with much of the ground covered by litter (table 2).

The canopy disturbance caused by landslides has favoured the growth of shrubs and herbaceous species (table 3), in particular, grasses and composite herbs. The "mature" portion of stand FC1 was included as a disturbed site when analysing the data for this table because it had been burnt relatively recently (c. 35 years ago). Many of the species recorded on the landslides are those more commonly found at higher altitudes. A comparison with appendix A of Jarman et al. (1984), reveals that 29 out of the 34 species found to be largely confined to the disturbed sites have not been recorded in thamnic rainforest. Fourteen of these have not been recorded in rainforest at all (table 2) and most of the remainder have previously been recorded only from open montane rainforest communities, that is those dominated by Athrotaxis cupressoides. Such forests are generally found at higher altitudes than those containing $A$. selaginoides, or in frost hollow situations (Cullen \& Kirkpatrick 1988).

A. selaginoides seedlings are common on the landslide faces at the six study sites, and seedling densities are greater for $A$. selaginoides than for any other tree species at all but one site (DR2, table 4). In three out of six cases, $A$. selaginoides seedlings are absent from adjacent mature forest despite the close proximity of adult $A$. selaginoides. The seedlings present in the mature forest at stands $\mathrm{FC} 2$ and VC2 are restricted to single patches close to the disturbed areas, suggesting that the loss of adjacent canopy cover may have produced conditions which favoured their growth. At stand FC1 the "mature" part of the study site was burnt at least 35 years ago (date obtained from ring counts on a fire damaged $A$. selaginoides stem). A number of adult A. selaginoides stems survived this fire and have provided a seed source for the burnt area and the landslide face. Thus, there is a heavy stocking of $A$. selaginoides regeneration in the "mature" section of the forest.

Nothofagus cunninghamii seedlings display a similar pattem to those of $A$. selaginoides. With the exception of stand $\mathrm{FCl}$, discussed above, seedling densities are higher in the disturbed areas than in the adjacent undisturbed forests. In fact, much of the $N$. cunninghamii regeneration in the mature forest is from basal sprouts rather than seedlings. These findings support those of Read \& Hill (1985, 1988a), who found that $N$. cunninghamii regenerates in canopy gaps and that many of the seedling-sized $N$. cunninghamii stems within undisturbed forests are basal sprouts.

At Mt Victoria Cross, Eucryphia milliganii is present on the disturbed sites in similar concentrations to $N$. cunninghamii. There are also a number of small diameter E. milliganii stems which may have been survivors from the previous forest or coppice regrowth from stems damaged in the landslides. Atherosperma moschatum and E. lucida were only recorded at stands FC2 and DR2. As seedlings, they occur in similar abundance in both the disturbed area and the mature forest at FC2. Seedling populations of these two species 
TABLE 2

Species Distribution and Cover Class

\begin{tabular}{|c|c|c|c|c|c|c|c|c|c|c|c|c|c|}
\hline \multirow[t]{4}{*}{ Species a nd family* } & \multirow{4}{*}{$\begin{array}{c}\text { Habit } \dagger \\
\text { and } \\
\text { habitat } \ddagger\end{array}$} & \multicolumn{12}{|c|}{ Stand designation } \\
\hline & & $\mathrm{VC3}$ & FC2 & DR2 & $\mathrm{VC2}$ & VC1 & FC1 & $\mathrm{VC3}$ & DR2 & $\mathrm{VC2}$ & VC1 & FC2 & FC1 \\
\hline & & \multicolumn{12}{|c|}{ Mature/undisturbed or disturbed } \\
\hline & & $\mathbf{M}$ & $\mathbf{M}$ & $\mathbf{M}$ & $\mathbf{M}$ & $\mathbf{M}$ & $\mathbf{M}$ & $\mathbf{D}$ & $\mathbf{D}$ & D & D & $\mathbf{D}$ & D \\
\hline Nothofagus gunnii (Fa) & $\mathrm{t}$ & - & - & - & - & - & - & - & - & - & - & - & + \\
\hline Olearia ledifolia $(\mathbf{C o})$ & $\mathrm{s} \mathrm{N}$ & - & - & - & - & - & - & - & - & - & - & - & + \\
\hline Orites milliganii $(\mathrm{Pr})$ & s I & - & - & - & - & - & - & - & - & - & - & - & + \\
\hline Helichrysum dendroideum $(\mathrm{Co})$ & h N & - & - & - & - & - & - & - & - & - & - & - & + \\
\hline Archeria comberi $(\mathrm{Ep})$ & $\mathrm{s} \mathrm{N}$ & - & - & - & - & - & - & - & - & - & $\rightarrow$ & - & + \\
\hline Epacris impressa (Ep) & $\mathrm{s} \mathrm{N}$ & - & - & - & - & - & - & - & - & - & - & - & + \\
\hline Libertia pulchella (Ir) & $\mathrm{h}$ & - & - & - & - & - & - & - & - & - & - & + & - \\
\hline Scirpus aucklandicus (Cy) & h GB & - & - & - & - & - & - & - & - & - & - & + & - \\
\hline Agrostis parviflora (Po) & h N & - & - & - & - & - & - & - & - & - & - & + & - \\
\hline Orites revoluta $(\mathrm{Pr})$ & $\mathrm{s} O \mathrm{M}$ & - & - & - & - & - & - & - & - & - & + & - & - \\
\hline Gentianella diemensis $(\mathrm{Ge})$ & h N & - & - & - & - & - & - & - & - & - & + & - & - \\
\hline \multicolumn{14}{|l|}{ Danthonia fortunae- } \\
\hline hibernae $(\mathrm{Po})$ & h G & - & - & - & - & - & - & - & - & - & + & - & - \\
\hline Carex spp. (Cy) & $\mathrm{h}$ & - & - & - & - & - & - & - & + & - & - & - & - \\
\hline Olearia phlogopappa (Co) & $\mathrm{s} O M$ & - & - & - & - & - & - & - & + & - & - & - & - \\
\hline Trochocarpa thymifolia (Ep) & s N & - & - & - & - & - & - & - & + & - & - & - & - \\
\hline Helichrysum ledifolium (Co) & s $N$ & - & - & - & - & - & - & - & 1 & - & - & - & - \\
\hline Cardamine spp. (Cr) & h N & - & - & - & - & - & - & - & + & - & - & - & - \\
\hline Cyathodes parvifolia $(\mathrm{Ep})$ & s HAC & - & - & - & - & - & - & - & 1 & - & - & - & - \\
\hline Senecio biserratus (Co) & hN & - & - & - & - & - & - & - & - & - & - & + & + \\
\hline Fpacris serpyllifolia (Ep) & s OM & - & - & - & - & - & $\ldots$ & - & - & - & + & - & 1 \\
\hline Luzula sp. (Ju) & $\mathrm{h} N$ & - & - & - & - & - & - & - & + & - & - & - & + \\
\hline Poa labillardieri (Po) & $\mathrm{h}$ & - & - & - & - & - & - & - & 2 & - & - & + & + \\
\hline P. gunnii $\left(\mathbf{P}_{0}\right)$ & h & - & - & - & + & - & - & 1 & - & + & + & + & + \\
\hline Richea sprengelioides (Ep) & s OM & - & - & - & - & 2 & - & - & 1 & 2 & 1 & - & + \\
\hline Hypolepis rugosula (De) & $\mathrm{pN}$ & - & - & - & - & - & + & - & + & - & - & 2 & + \\
\hline Gaultheria hispida (Er) & s $N$ & - & - & - & - & - & + & - & + & $-\cdots$ & + & - & + \\
\hline Leptospermum scoparium (My) & t I & - & - & - & - & 2 & - & + & - & 2 & 1 & - & - \\
\hline Epilobium spp. (On) & h G & - & - & - & - & - & 1 & - & - & - & - & + & 1 \\
\hline Helichrysum adenophorum (Co) & $h \mathrm{~N}$ & - & - & - & - & - & + & - & - & - & - & + & + \\
\hline Gnaphalium spp. (Co) & $\mathrm{h} \mathrm{N}$ & - & - & - & + & - & - & - & + & + & - & - & - \\
\hline Juncus spp. (Ju) & h N & - & - & - & - & - & + & - & - & - & - & + & + \\
\hline Oreobolus oxycarpus (Cy) & h OM & - & - & - & + & + & - & + & - & + & + & - & - \\
\hline Brachycome tenuiscapa (Co) & $\mathrm{h} N$ & - & - & - & + & + & - & + & - & + & + & - & - \\
\hline Helichrysum backhousii (Co) & s OM & - & - & - & - & 1 & + & - & - & 2 & 1 & - & 1 \\
\hline Richea scoparia $(\mathrm{Ep})$ & $s / t$ & 2 & + & - & - & 2 & 1 & 2 & 1 & + & + & - & 1 \\
\hline Athrotaxis selaginoides (Ta) & $t$ & 1 & 2 & - & 1 & 1 & 1 & 2 & 1 & 1 & 1 & 1 & 1 \\
\hline Nothofagus cuntinghamii $(\mathrm{Fa})$ & $\mathrm{t}$ & 2 & 2 & 3 & 2 & 2 & 1 & 1 & 1 & 1 & 1 & 1 & 1 \\
\hline Coprosma nitida $(\mathrm{Ru})$ & s & + & - & 1 & - & + & 1 & - & 1 & + & 1 & - & + \\
\hline Tasmania lanceolata (Wi) & $\mathrm{s}$ & - & - & 1 & + & + & + & + & - & + & + & - & 1 \\
\hline Richea pandanifolia $(\mathrm{Ep})$ & $s / t$ & 2 & 1 & - & + & 1. & 1 & - & - & + & + & - & 1 \\
\hline Polystichum proliferum (As) & $\mathrm{p}$ & + & 1 & 1 & - & - & + & - & 1 & - & - & + & 1 \\
\hline Eucryphia milliganii(Mo) & $\mathrm{t}$ & 2 & + & - & 2 & 2 & - & 1 & - & 1 & 1 & - & - \\
\hline Orites diversifolia $(\mathrm{Pr})$ & s & + & + & - & + & + & - & 2 & - & 2 & 1 & - & - \\
\hline Blechnum wattsii $(\mathrm{Bl})$ & $\mathrm{p}$ & + & 1 & - & - & - & + & - & - & - & + & + & + \\
\hline Oxalis lactea $(\mathrm{Ox})$ & $\mathrm{h}$ & + & - & - & - & + & - & - & - & - & - & + & + \\
\hline Histiopteris incisa (De) & $\mathrm{p}$ & + & + & - & - & - & 1 & - & - & - & - & 2 & + \\
\hline Lycopodium spp. (Ly) & $\mathrm{p}$ & - & - & - & - & - & + & - & - & - & - & - & + \\
\hline Acaena montana $(\mathrm{Ro})$ & hN & - & - & - & + & - & - & - & - & + & - & - & - \\
\hline Senecio leptocarpus (Co) & h N & - & - & - & - & - & + & - & - & - & - & - & + \\
\hline
\end{tabular}


Habit $y$ Stand designation

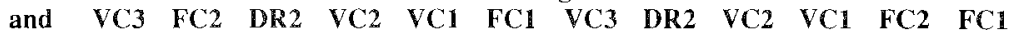

habitat:

Mature/undisturbed or disturbed

$\begin{array}{llllllllllll}\mathbf{M} & \mathbf{M} & \mathbf{M} & \mathbf{M} & \mathbf{M} & \mathbf{M} & \mathbf{D} & \mathbf{D} & \mathbf{D} & \mathbf{D} & \mathbf{D} & \mathbf{D}\end{array}$

Exocarpos humifusus (Sa)
Hierochloe fraseri $(\mathrm{Po})$

Eucalyptus vernicosa (My)

Oreobolus acutifolius (Cy)

Isophysis tasmanica (Ir)

Euphrasia striata $(\mathrm{Sc})$

Aceana novae-zelandiae (Ro)

Archeria serpyllifolia (Ep)

Lagenophora stipitata (Co)

Senecio pectinatus $(\mathrm{Co})$

Epilobium billardierianum (Co)

Eucryphia lucida (Mo)

Olearia pinifolia $(\mathrm{Co})$

Uncinia tenella $(\mathrm{Cy})$

Plantago daltonii (Pl)

Anopterus glandulosus (Sax)

Olearia persoonioides (Co)

Archeria hirtella $(\mathrm{Ep})$

Cyathodes juniperina (Ep)

Astelia alpina (Li)

Trochocarpa cunninghamii (Ep)

Prionotes cerinthoides (Ep)

Grammitis billardieri $(\mathrm{Gr})$

Phyllocladus aspleniifolius (Pod)

Atherosperma moschatum (At)

Archeria eriocarpa (Ep)

Telopea truncata $(\mathrm{Pr})$

Pittosporum bicolor (Pi)

Blandfordia punicea $(\mathrm{Li})$

Ranunculus spp. (Ra)

Plantago spp. (P1)

Drosera arcturi (Dr)

Prasophyllum spp. (Or)

Carpha alpina (Cy)

Aristotelia peduncularis (Ti)

Monotoca submutica (Ep)

Trochocarpa gunnii (Ep)

Diplarrena latifolia (Ir)

Apteropteris applanata $(\mathrm{Hy})$

Diplaspis cordifolia (Um)

Grammitis poeppegania $(\mathrm{Gr})$

s OM

hN

s/t N

h OM

h N

h N

h N

s I

h

h N

$h \mathrm{~N}$

t

SOM - -

$\begin{array}{lllll}\mathrm{h} & + & - & - & + \\ \mathrm{h} & + & - & - & + \\ \mathrm{s} & - & + & - & -\end{array}$

$\begin{array}{ccccc}\mathrm{s} & - & + & - & - \\ \mathrm{sI} & - & - & - & -\end{array}$

$\begin{array}{llll}\mathrm{s} & - & + & -\end{array}$

$\begin{array}{lllll}\mathrm{s} & + & - & - & + \\ \mathrm{h} & + & + & - & +\end{array}$

$\begin{array}{lllll}\mathrm{h} & + & + & - & + \\ \mathrm{s} & + & + & - & -\end{array}$

$s$

e

$p$

t

$t-2$

s + + -

$\begin{array}{cc}\mathrm{s} & - \\ \mathrm{s} / \mathrm{t} & - \\ \mathrm{h} & -\end{array}$

$\mathrm{h}$

hN - - - -

h OM

h N

h N

s I

s I

h

h N

p N

* Families: $\mathrm{As}=$ A spidaceae, $\mathrm{At}=$ Atherospermataceae $, \mathrm{Bl}=\mathrm{Blechnaceae}, \mathrm{Co}=$ Compositae $, \mathrm{Cr}=\mathrm{Cruciferae}, \mathrm{Cy}=\mathrm{Cyperaceae}$, $\mathrm{De}=$ Dennstaedtiaceae, $\mathrm{Ep}=$ Epacridaceae, $\mathrm{Er}=$ Ericaceae, $\mathrm{Fa}=$ Fagaceae, $\mathrm{Ge}=$ Gentianaceae, $\mathrm{Gr}=$ Grammitidaceae, $\mathrm{Hy}=$ Hymenophyllaceae, $\mathrm{Ir}=$ Iridaceae, $\mathrm{Ju}=\mathrm{Juncaceae}, \mathrm{Mo}=$ Monomiaceae, $\mathrm{My}=$ Myrtaceae, $\mathrm{On}=$ Onagraceae, $\mathrm{Or}=$ Orchidaceae, $\mathrm{Pi}=$ Pittosporaceae, $\mathrm{Pl}=$ Plantaginaceae, $\mathrm{Po}=$ Poaceae, $\mathrm{Pod}=$ Podocarpaceae, $\mathrm{Pr}=$ Proteaceae, $\mathrm{Ra}=$ Ranunculaceae, $\mathrm{Ro}=$ Rosaceae, $\mathrm{Ru}=$ Rubiaceae, $\mathrm{Sa}=$ Santalaceac, $\mathrm{Sax}=$ Saxifragaceae, $\mathrm{Sc}=$ Scrophulariaceae, $\mathrm{Ta}=$ Taxodiaceae, $\mathrm{Ti}=\mathrm{Tiliaceae}$, $\mathrm{Ox}=$ Oxalidaceae, $\mathrm{Um}=$ Umbelliferae, $\mathrm{Wi}=$ Winteraceae.

† Habit: $\mathrm{e}=$ epiphyte, $\mathrm{h}=$ herb, $\mathrm{p}=$ pteridophyte, $\mathrm{s}=$ shrub, $\mathrm{t}=$ tree.

$\ddagger$ Habitat (from Jarman et al. 1984 ): $\mathrm{B}=$ rainforest bogs, $\mathrm{G}=$ gallery rainforest, $\mathrm{HAC}=$ high altitude callidendrous rainforest, $\mathrm{I}=$ recorded in implicate rainforest, $\mathrm{N}=$ not recorded in rainforest, $\mathrm{OM}=$ open montane rainforest. 
TABLE 3

Summary of Table 2 by Lifeform and Family

\begin{tabular}{lcc}
\hline Lifeform & Disturbed & Undisturbed \\
\hline Poaceae & 11 & 1 \\
Compositae (herbs) & 16 & 6 \\
Compositae (others) & 11 & 4 \\
All herbaceous species & 60 & 27 \\
Epacridaceae (shrubs) & 27 & 20 \\
\hline
\end{tabular}

TABLE 4

Seedling Densities (per $\mathrm{m}^{2}$ ) at the Study Sites

\begin{tabular}{|c|c|c|c|c|c|c|c|c|c|c|c|c|}
\hline \multirow[t]{2}{*}{ Species } & \multicolumn{12}{|c|}{ Stands* } \\
\hline & FC1d & FC1 & FC2d & FC2 & VC1d & VC1 & VC2d & $\mathrm{VC2}$ & VC3d & $\mathrm{VC3}$ & DR2d & DR2 \\
\hline Athrotaxis selaginoides & 0.14 & 0.63 & 2.16 & 0.04 & 0.12 & & 0.27 & 0.07 & 1.05 & & 0.16 & \\
\hline Nothofagus cunninghamii & 0.06 & 0.13 & 0.91 & 0.10 & 0.05 & 0.03 & 0.07 & 0.02 & 0.68 & 0.13 & 0.46 & $\mathrm{~nm}$ \\
\hline Atherosperma moschatum & & & 0.02 & 0.03 & & & & & & & & \\
\hline Eucryphia lucida & & & 0.02 & 0.04 & & & & & & & & \\
\hline Eucryphia milliganii & & & & & 0.05 & 0.06 & 0.06 & 0.04 & 0.29 & & & \\
\hline Leptospermum scoparium & & & & & 0.02 & & & & 0.02 & & & \\
\hline
\end{tabular}

* $\mathrm{d}=$ disturbed area, $\mathrm{nm}=$ not measured.

were not investigated at stand DR2. Phyllocladus aspleniifolius was only recorded in low numbers at three of the sites and only once, as a seedling, on a disturbed area. This is somewhat surprising, as $P$. aspleniifolius is common in disturbed plant communities in western Tasmania (Kirkpatrick 1977). Read \& Hill (1988a) found demographic structures for this species to be suggestive of past catastrophic disturbances. The virtual absence of $P$. aspleniifolius from the landslide faces may be explained by a lack of seed, as there are few mature trees of the species in the surrounding forests.

The presence of Eucalyptus vernicosa at stand FC1 and that of Leptospermum scoparium at stands VC1, $\mathrm{VC} 2$, and VC3 warrants further discussion.

Three E. vernicosa individuals were recorded at stand $\mathrm{FC} 1$. One is a seedling on the landslide face and two adults occur on the site which had been burnt in the past. Eucalyptus regeneration is usually associated with fire but Eucalyptus coccifera has been observed regenerating without disturbance in mixed $E$. coccifer
-Athrotaxis cupressoides -Nothofagus gunnii communities in the central highlands (author's observations). Jarman \& Brown (1983) consider that Eucalyptus species may be able to regenerate in some subalpine environments in the absence of fire. Infrequent catastrophic disturbances, such as landslides, may provide limited opportunities for Eucalyptus species to persist without fire in communities that contain extremely fire sensitive species.

Leptospermum scoparium is present on all the landslides areas at Mt Victoria Cross and there are a few large individuals in the undisturbed forest at stand VC1. $L$. scoparium is a common early seral species in regenerating podocarp forest in New Zealand (Cameron 1960). It has been recorded as a pioneer species on landslides in southern New Zealand (Mark et al. 1964). They found that it still occupied an important position in the canopy 50 years after disturbance but that its lifespan was only approximately 100 years. The success of $L$. scoparium on these sites was attributed to its high drought tolerance. 


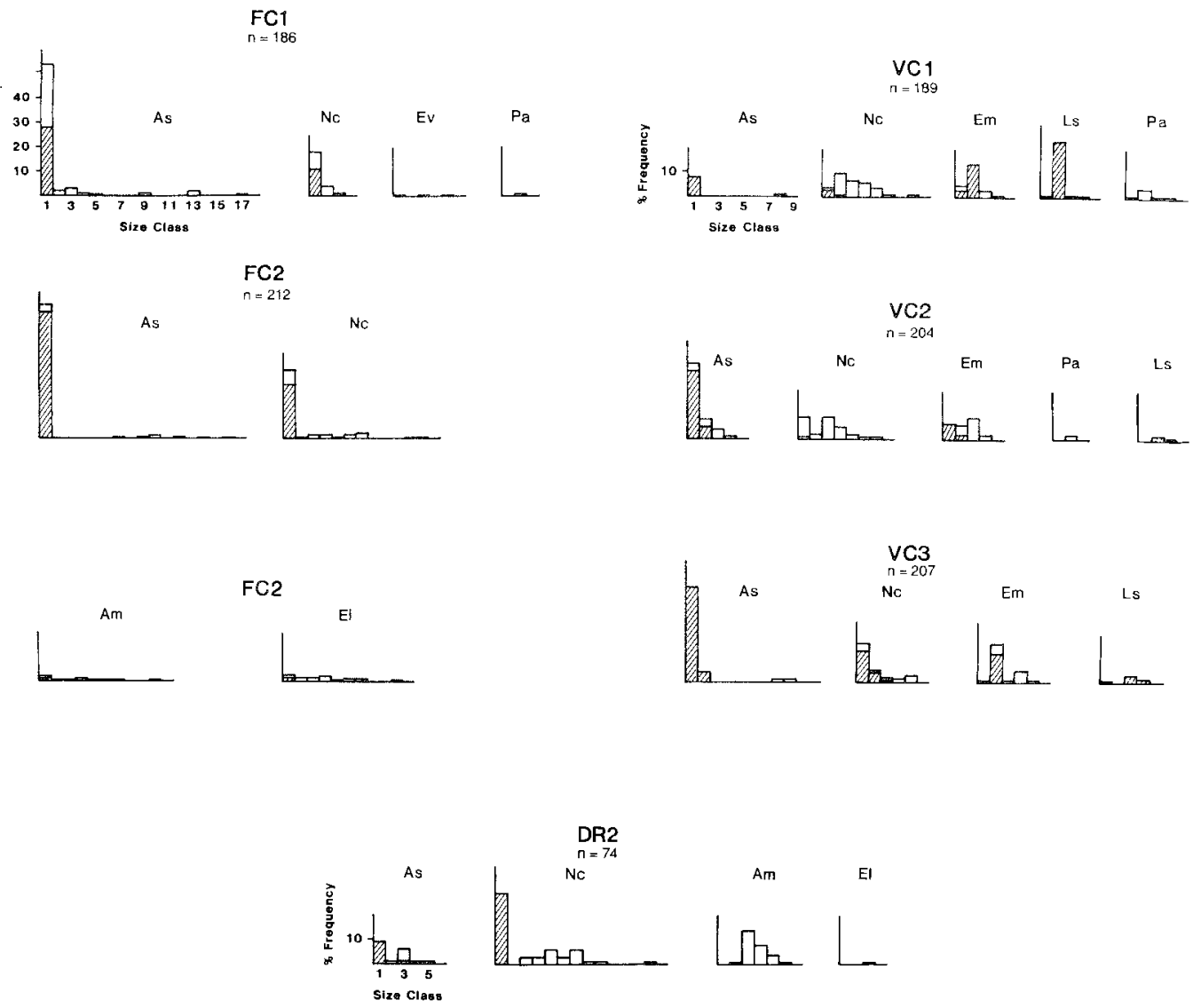

FIG. 2 - Percentage frequency versus size class for tree species recorded on the transects. Size classes are: $1=<10 \mathrm{~mm}$ d.b.h., $2=10-95 \mathrm{~mm}, 3=100-195 \mathrm{~mm}$, and so on. Hatched areas represent the proportion of seedlings located on landslide faces. $n=$ total number of stems measured at each stand. Species are: $A m=$ Atherosperma moschatum, $A s=$ Athrotaxis selaginoides, $E v=$ Eucalyptus vernicosa, $E l=$ Eucryphia lucida, $E m=$ Eucryphia milliganii, $L s=$ Leptospermum scoparium, $N c=$ Nothofagus cunninghamii, $P a=$ Phyllocladus aspleniifolius.

The role of Leptospermum species in Tasmanian rainforest communities remains uncertain. Jarman \& Brown (1983) consider Leptospermum riparium to be a "true" rainforest species in gallery rainforests but the status of L. nitidum, L. lanigerum, and $L$. scoparium is unclear. These species are largely associated with fire prone vegetation. However, $L$. lanigerum may be capable of regeneration in rainforest in canopy gaps created by its own death. Gibson et al. (1987) found L. lanigerum to be regenerating in canopy gaps and at stand edges in swamp forests that may be edaphically deflected climax rainforests. The results of the present study suggests that $L$. scoparium could maintain its presence in rainforests, provided that disturbances reoccurred within the lifespan of the species.
The histograms of the size/class structure of the forests investigated are presented in figure 2 . The proportion of $A$. selaginoides seedlings occurring on the disturbed sites and in the undisturbed forest at each site is shown. The lack of $A$. selaginoides regeneration and the presence of only large-sized $A$. selaginoides stems in the undisturbed rainforest at all the sites investigated supports the contention that the species requires canopy disturbances for adequate regeneration in evergreen rainforest (Cullen 1987a). The forest at Mt Victoria Cross is very similar in composition and structure to a stand of evergreen rainforest at Mt Anne (stand A2 in Cullen 1987b). At the time of documentation there was no canopy disturbance and there were no small-sized A. selaginoides individuals at the Mt Anne stand. 
Likewise, the mature forest at stand $\mathrm{FC} 2$ was similar to that of stand B3 at Mt Bobs (see Cullen 1987b) where the only $A$. selaginoides regeneration present was located in a gap caused by the fall of a mature $N$. cunninghamii stem.

The necessity for canopy disturbance is clearly demonstrated at stand DR2. Mature $A$. selaginoides trees overhang the cliffs above and would provide seed to both a gap created by rockfall and to the adjacent closed thamnic rainforest. A. selaginoides regeneration is only present on the disturbed area. The other stands of $A$. selaginoides in this area may have been initiated in a similar manner. They occur on steep, rocky slopes below dolerite crags, are of limited extent and contain no small-sized individuals.

Increment cores obtained from individuals at $\mathrm{VC} 3$ and DR2 indicate that the sites have been open to $A$. selaginoides recruitment for periods of between 50 and 100 years. The largest stem at DR2 was aged at a minimum of 33 years (core extracted at ground level), but the site appears to be still open to regeneration of the species. Adjacent to this gap, a group of pole sized $A$. selaginoides and $N$. cunninghamii stems occupy an area which appears to have been disturbed over 100 years ago. This area lacks $A$. selaginoides seedlings. Two $A$. selaginoides stems yielded minimum ages of 50 and 112 years (cores extracted $1 \mathrm{~m}$ above ground level), again indicating a prolonged recruitment period. A burnt site at Mt Bobs (see Cullen 1987b) appears to have been open to $A$. selaginoides regeneration for 60 to 70 years.

At stand VC3, 15 mature individuals ranging in size from 200 to $605 \mathrm{~mm}$ d.b.h. were aged. They form part of a stand which is orientated orthogonal to the contours. This stand is approximately $15 \mathrm{~m}$ wide and $100 \mathrm{~m}$ long. Minimum ages for these stems also suggest that they were recruited over a period of approximately 70 years. The stand contains no small stems or seedlings. The age structure and spatial distribution of the stems strongly support the contention that the stand germinated on a past landslide.

It appears that extended periods of $A$. selaginoides seedling recruitment may be normal on catastrophically disturbed sites. The extended recruitment of faster growing species would create multi-age/multi-size class stands. However, the extremely slow growth rates and the great longevity of $A$. selaginoides result in what appear to be more or less even-aged stands, despite the fact that the individuals have been recruited over a long time-period. Stands with size/age structures which can be attributed to extended recruitment periods have been recorded at many locations (Cullen 1987b, Kirkpatrick \& Harwood 1980, Ogden 1978, Read \& Hill 1988a).

Landslides were very common on the steep sandstone slopes below the dolerite cliffs which form many of the peaks in the Southern Range; 255 were counted on the aerial photographs. They occurred in an area of $160 \mathrm{~km}^{2}$ which supports many living and burnt stands of A. selaginoides (Brown 1988). In addition, there were at least as many small areas of disturbed ground which may have been caused by slope failure. The rate at which landslides occur could be assessed in the future if another set of aerial photographs is produced for the region. Observations during fieldwork indicate that landslides are relatively common at the other study areas and in other regions supporting cool temperate rainforest, for example, the lower Gordon River Valley (Mike Pemberton, pers. comm.)

\section{GENERAL DISCUSSION}

The impact of landslides is likely to be intermediate between that of minor events such as treefall gaps and more extensive events such as wildfires. Consequently, landslides are likely to create unique regeneration niches in rainforest communities.

At all the sites visited, the extent of canopy disturbance was much greater than that likely to occur with the wind throw of one or a small group of trees. In small canopy gaps, light-demanding species such as $A$. selaginoides will be at a disadvantage. The amount of light reaching the forest floor will be less in small canopy gaps, especially as the surrounding adult trees will have a tendency to expand to occupy the vacant canopy space, causing suppression of regenerating seedlings.

The temperature regime is likely to be more extreme on a landslide face than in a treefall gap. Nunez \& Bowman (1986) found that there was little difference between the nightly minimum temperatures experienced in unlogged forest and in those where $42 \%$ of stems had been removed, but minimum temperatures were $3-4^{\circ} \mathrm{C}$ lower on an adjacent clear-felled site and resulted in repeated, severe frosts. In high light, low temperature situations, A. selaginoides is capable of higher growth rates than $N$. cunninghamii, Atherosperma moschatum, E. lucida and P. aspleniifolius (Read 1985); it is marginally less frost resistant than N. cunninghamii but more frost resistant than A. moschatum, E. lucida and P. asplenilfolius (Read \& Hill 1988b). This could account, at least in part, for its success as a coloniser of landslide sites. The presence of species usually found in open montane rainforests or alpine vegetation may reflect a higher incidence of frost on these sites. Once established, these species would provide the necessary cover for less hardy species to establish.

Landslides remove all or most of the subcanopy and ground cover. Alternatively, treefalls or canopy damage from wind or snowstorms will leave the subordinate 
vegetation møre or less intact. Thus, shade-tolerant tree and shrub species which are present in the understorey and survive the disturbance will be at an advantage.

On the other hand, disturbances caused by landslides will be less extensive than those caused by all but the most localised fires. Unlike fires, landslides are not likely to create disturbance beyond the seed dispersal range of poorly dispersed species such as A. selaginoides, and complete clearance of the landslide face will remove those species which can regenerate vegetatively following burning, thus reducing the competition for new seedlings.

The frequency and extent of catastrophic disturbances, other than fire, which can create conditions suitable for the regeneration of $A$. selaginoides are not known. Landslides and rockfalls must be considered to be an integral part of the environment in at least some mountainous regions in Tasmania. These events and others, such as windstorms and heavy snowfalls, are likely to be more common in mountain environments than at lower altitudes, and a lack of disturbance events suitable for $A$. selaginoides regeneration may be a contributing factor controlling the distribution of the species at low elevations.

The incidence of disturbances which would promote A. selaginoides regeneration is likely to have been much higher during colder climates prevailing during the last glacial and preceding interstadial than at present. Glacial climates produced greater slope instability than occurs now or during most of the Holocene (Kiernan 1985). In the Cascade Range of northwestern USA, Oliver $e t$ al. (1985) found that the alternating advance and retreat of a glacier, rockfalls, avalanches and other events caused widespread disturbance in forested areas adjacent to the glacier. Wardle $(1973,1980)$ has investigated similar phenomena in New Zealand. The glaciers on the West Coast Range of Tasmania, and possibly further inland, would have been similar to those found in New Zealand and Patagonia at present (Kiernan 1980, 1985). It is reasonable to assume that the glaciers in Tasmania extended down to and below the treeline on occasions, creating conditions similar to those reported by Oliver et al. (1985) and Wardle (1973). Disturbance caused by heavy snowfalls and avalanches is also likely to be increased during a colder climate.

\section{CONCLUSION}

The results of this study indicate that landslides can provide opportunities for Athrotaxis selaginoides seedling establishment. The extent and nature of the disturbance caused when landslides occur in rainforest appears to be well suited to the physiology and poor seed dispersal of $A$. selaginoides and may provide opportunities for the development of new stands of the species. Large numbers of landslides have occurred in the Southern Range, suggesting that they are an integral part of the steep slope, rainforest environment, at least in this region.

The incidence of landslides and other forms of disturbance which can promote $A$. selaginoides regeneration are likely to have been more common during glacial and interstadial periods. Thus, the species may have been advantaged in these times.

Seedling distribution on the landslide faces indicates that Nothofagus cunninghamii can also regenerate on these sites. In addition, landslides might provide opportunities for limited regeneration of Eucalyptus and Leptospermum species. Whether landslides occur with sufficient regularity to maintain these minor species within rainforest communities is not known.

\section{ACKNOWLEDGEMENTS}

I wish to thank the following people: Sian Smith and Mark Neyland for assistance in the field, Jamie Kirkpatrick, who provided constructive criticism and continued support, Airlie Alam for preparing the illustrations and Rosie Bickel for typing the manuscript. The project was undertaken through the Department of Geography and Environmental Studies, University of Tasmania and was funded by a grant from the Office of the National Estate to the Tasmanian Conservation Trust. Assistance was also provided by the Tasmanian Department of Parks, Wildlife and Heritage World Heritage Directed Research Program.

\section{REFERENCES}

Beveridge, J.L., 1973: Regeneration of podocarps in central North Island podocarp forests. Proc. NZ Ecol. Soc. 11: 48-55.

Brown, M.J., 1988: Distribution and conservation of King Billy Pine. A report to the World Wildlife Fund Ausiralia.

Buchanan, A.M., McGeary-Brown, A. \& Orchard, A.E., 1989: A CENSUS OF THE VASCULAR PLANTS OF TASMANIA. Tasm.. Herb. Occas. Publ. 2.

Burke, W.D., 1974: Regeneration of podocarps on $\mathrm{Mt}$ Tarawera, Rotorua. NZ J. Bot. 12: 219-226.

CAMERON, R.J., 1960: Natural regeneration of podocarps in the forests of the Whirinaki River Valley. NZJ.For. 8: $337-364$

Clayton-Greene, K.A., 1977: Structure and origin of Libocedrus bidwillii stands in the Waikato district, New Zealand. NZ J. Bot. 15: 19-28.

Cullen, P.J., 1987a: Regeneration in populations of Athrotaxis selaginoides D. Don from Tasmania. J. Biogeog. 14: 39-51.

Cullen, P.J., 1987b: The ecology and biogeography of Athrotaxis D. Don. Unpubl. MSc lhesis. Department of Geography, University of Tasmania. 
Cullen, PJ. \& Kirkpatrick, J.B., 1988: The ecology of A throtaxis D. Don (Taxodiaceae) II. The distributions and ecological differentiation of $A$. cupressoides and A. selaginoides. Aust. J. Bot. 36: 547-560.

Gibson, N., Williams, K. \& Brown, M.J., 1987: Regeneration characteristics of a swamp forest in northwestern Tasmania. Pap. Proc. R. Soc. Tasm. 121: 93-100.

Hughes, J.M.R., 1987: A study of riverine plant communities in Tasmania. Unpubl. PhD thesis, Department of Gregraphy, University of Tasmania.

Hutchinson, F.E., 1932: The life history of the Westland rimu bush. Te Kura Ngahere 3: 54-61.

JACKSON, W.D., 1968: Fire, air, water and earth, an elemental ecology of Tasmania. Pap. Proc. Ecol. Soc. Aust. 3: 9-16.

JARMAN, S.J. \& BRowN, M.J., 1983: A definition of cool temperate rainforest in Tasmania. Search. 14: 8187.

Jarman, S.J., Brown, M.J. \& Kantvilas, G., 1984: RAINFOREST IN TASMANIA. National Parks and Wildlife Service Tasmania.

Kiernan, K, 1980: Pleistocene glaciation of the central West Coast Range, Tasmania. Unpubl. BSc Hons thesis, University of Tasmania.

KIERNAN, K, 1985: Late Cainozoic glaciation and mountain geomorphology in the Central Highlands of Tasmania. Unpubl. PhD thesis, University of Tasmania.

KIRKPATRICK, J.B., 1977: The impact of man on the vegetation of the West Coast region, Tasmania. In Banks., M.R. \& Kirkpatrick, J.B. (Eds): LANDSCAPE AND MAN. Royal Society of Tasmania, Hobart.

KIRKPATRICK, J.B. \& Dickinson, K.J.M., 1984a: The impact of fire on Tasmanian alpine vegetation and soils. Aust. J. Bot. 32: 613-629.

KirKPATRICK, J.B. \& DiCKINSON, K.J.M., 1984b: VEGETATION OF TASMANIA (MAP). Forestry Commission of Tasmania, Hobart.

KirkPatrick, J.B. \& HaRWOOD, C.E., 1980: Vegetation of an infrequently burned Tasmanian mountain region. Proc. R. Soc. Vict. 91: 79-107.

LLOYD, R.C., 1960: Growth study of regenerated Kauri and podocarps in Russell Forest. NZ J. For. 8: 341-355.

McKelyey, P.J., 1953: Forest colonization after recent volcanicity at West Taupo. NZ J. For, 6: 435-448.

MARK, A.F., SCOTT, G.A.N., SANDERSON, F.R. \& JAMES, P.W., 1964: Forest succession on landslides above Lake Thomson, Fiordland. NZ J. Bot. 2: 60-89.

MinCHIN, P.R., 1986: HOW TO USE ECOPAK: AN ECOLOGICAL DATABASE SYSTEM. Technical Memorandum 86/6. CSIRO, Canberra.

Mount, A.B., 1979: Natural regeneration processes in Tasmanian forests. Search 10: 180-186.

NoRTon, D.A. 1983: The population dynamics of subalpine Libocedrus bidwillii forests in the Cropp River Valley, Westland, New Zealand. NZ.I. Bot. 21: 127134.

Nunez, M. \& Bowman, D.M.J.S., 1986: Noctumal cooling in a high altitude stand of Eucalyptus delegatensis as related to stand density. Aust. For. Res. 16: 185-197.
OGDEN, J., 1978: Investigations of the dendrochronology of the genus Athrotaxis D. Don. (Taxodiaceae) in Tasmania. Tree-Ring Bull. 38: 1-13.

Oliver, C.D., Adams, A.B. \& Zasoski, R.J., 1985: Disturbance patterns and forest development in a recently deglaciated valley in the northwestern Cascade Range of Washington, U.S.A. Can. J. For. Res. 15: 221-232.

READ, J., 1985: Photosynthetic and growth responses to different light regimes of the major canopy species of Tasmanian cool temperate rainforest. Aust.J. Ecol. 10: $327-334$.

READ, J. \& Hill, R.S., 1985: Dynamics of Nothofagus dominated rainforest on mainland Australia and lowland Tasmania. Vegetatio 63: 67-78.

READ, J. \& Hill, R.S., 1988a: The dynamics of some rainforest associations in Tasmania. J. Ecol. 76: 558-584.

READ, J. \& HILL, R.S., 1988b: Comparative responses to temperature of the major canopy species of Tasmanian cool temperate rainforest and their ecological significance. I. Foliar frost resistance. Aust. J. Bot., 36:131-143.

VEBLEN, T.T., 1982: Regeneration patterns in Araucaria araucana forests in Chile. J. Biogeogr. 9: 11-28.

Veblen, T.T. \& Ashton, D.H., 1978: Catastrophic influences on the vegetation of the Valdivian Andes, Chile. Vegetatio 36: 149-167.

Veblen, T.T. \& Lorenz, D.C., 1987: Post-fire stand development of Austrocedrus-Nothofagus forests in northern Patagonia. Vegetatio 71: 113-126.

Verlen, T.T., Schlegel F.M. \& Oltremari, J.V., 1983: Temperate broad-leaved evergreen forests of South America. In Ovington, J.D. (Ed.): TEMPERATE BROAD-LEAVED EVERGREEN FORESTS. Elsevier Scientific Publishers, Amsterdam.

Veblen, T.T. \& Stewart, G.H., 1982: On the conifer regeneration gap in New Zealand: the dynamics of Libocedrus bidwillii stands on South Island. J. Ecol. 70: 413-436.

WARDLE, J.A., 1970: The ecology of Nothofagus solandri. 1. The distribution and relationships with other major forest and scrub species. NZ J. Bot. 8: 494-531.

WARDLE, J.A., 1974: The life history of mountain beech (Nothofagus solandri var. cliffortiodes). Proc. NZ Ecol. Soc. 21: 21-26.

WARDLE, P., 1973: Variations of the glaciers of Westland National Park and the Hooker Range, New Zealand. NZ J. Bot. 11: 349-388.

WardLe, P., 1980: Primary succession in westland National Park and its vicinity, New Zealand. NZ J. Bot. 18: 221-232.

WHITE, P.S., 1979: Pattern, process and natural disturbance in vegetation. Bot. Rev. 45: 229-299.

\section{(accepted 10 August 1990)}

\section{P. Cullen}

Department of Geography, ANU, GPO Box 4, Canberra, ACT, Australia 2601; formerly Department of Geography and Environmental Studies, University of Tasmania 